\title{
The tale of academic practice in a rising knowledge society: focus on a university in South Africa
}

\author{
Florence Ndibuuza ${ }^{1}$ (D) Patricio Langa ${ }^{1}$
}

Received: 15 November 2018 / Accepted: 31 May 2019/Published online: 15 June 2019

(C) The Author(s) 2019

\begin{abstract}
This paper is based on a study conducted to establish if academic practice in a university designated as Azania is aligning or diverting from the expectations of the rising knowledge society in South Africa. The paper is motivated by the emerging national needs specific to the production, dissemination and application of knowledge as the country takes steps towards knowledge led development. The general assumption is that academic practice in universities is spontaneously responding to the needs of its changing environment. Thus, to establish the position of academic practice in Azania, institutional and national documents were examined from a neo-institutional perspective through qualitative discourse analysis. The results showed that research, teaching and outreach at the University was responding to national needs. Thus, academic practice in Azania is aligning more than diverting from the expectations of the rising knowledge society. However, considering that the study based on only document analysis a focus on other data sources is recommended.
\end{abstract}

Keywords Academic practice $\cdot$ Rising knowledge society $\cdot$ Neo-institutionalism $\cdot$ University

\section{Introduction}

This paper explores the uncertainty surrounding academic practice in South Africa. It examines how universities in the country are embracing national hopes of a knowledge society in what is viewed as a changing context of operation (Ndofirepi 2017). We define the knowledge society from the angle of knowledge put to use as a key factor in economic and social

Electronic supplementary material The online version of this article (https://doi.org/10.1007/s11233-01909036-x) contains supplementary material, which is available to authorized users.

Florence Ndibuuza

3774891@myuwc.ac.za; ndibuuzaf@gmail.com

Patricio Langa

planga@uwc.ac.za; planga@gmail.com

1 Faculty of Education, University of the Western Cape, Private Bag X17, Cape Town, Republic of South Africa 
development (Ndofirepi 2017; Snellman 2015). Higher education as one of the key sources of knowledge has been identified as a key player for such contemporary societies if universities can produce, disseminate and apply knowledge beyond the walls of academia (Boaventura 2010; Cernat 2011; Snellman 2015). The implication is an expanded mandate for universities reflected in the demand for academia to rise to contemporary societal needs. Thus, the growing significance of academic work in developing knowledge relevant to the needs of South Africa has motivated this study.

The current research indicators of knowledge societies are inconclusive on whether South Africa has achieved the status of a knowledge society (Britz et al. 2006; Holmner 2008; Jiyane et al. 2013). That is, the three studies identified shortfalls in indicators like access and use of ICT, intellectual capital, investment in research and development, research output and the number of patents. South Africa can actually best be described as an industrial middle-income economy with vibrant mining, agricultural and manufacturing sectors (Industrial Development Corporation 2017; OECD 2015). This means that it still depends more on natural and physical resources for development contrary to a knowledge society. It is not surprising therefore that Britz et al. (2006) noted that Africa, South Africa inclusive, is still far from knowledge society status. However, though Jiyane et al. (2013) discovered that South Africa does not satisfy most of the indicators of a knowledge society, they also observed that it was in transit to a knowledge society with the indicators they satisfy. In any case, UNESCO (2016) suggests that there is no single model of what a knowledge society should be and that it is possible for agricultural and industrial economies to jump straight into the knowledge society stage, hence the term rising knowledge society in acknowledgment of South Africa's stage of development.

For this rising knowledge society, the National Development Plan has laid out expectations for higher education specific to the production of the knowledge necessary to position the nation among global knowledge societies (National Planning Commission 2011). In essence, universities and consequently academic practice have an obligation to the country akin to Altbach (2013)'s recognition of a university as a key entity for a knowledge society. It is against this background that the study focuses on a public university designated Azania to examine academic practice in relation to the expectations of a rising knowledge society.

The article answers one main research question: Is academic practice aligning or diverting from the expectations of a rising knowledge society? Is research, teaching and outreach in University Azania responding to the expectations of the rising knowledge society in South Africa? To answer the question, the paper presents evidence from an empirical qualitative discourse analysis using national and institutional documents. In addition to the introduction, this paper covers an overview of the university under study. In the subsequent sections, a brief literature review on academic practice and the rising knowledge society, the theoretical framework, method, results and discussion as well as the conclusion sections of the study are discussed respectively.

\section{Overview of the study context}

University Azania is one of the historically disadvantaged universities in South Africa with a history of resistance against apartheid and oppression (Daniels 2018). This university is regarded as a vanguard of the nation's historic change upon which it is committed to aid intellectual, social and economic progress in democratic South Africa (Daniels 2018). In the quest of fulfilling its mandate, Azania draws students from across the country and from all 
racial backgrounds a number that amounts to 22,443 students, supported by 678 academics (Department of Higher Education and Training 2018).

Although the debate on the knowledge society has tended to take a national approach, it is important to understand how institutions especially the historically disadvantaged ones are taking this mandate and integrating it in teaching, research and outreach. Important to note is that the Institutional Operational Plan (IOP) of the University 2016-2020 acknowledges that as a public institution, it has a role to play in tackling national concerns (IOP 2016). One of the key concerns the plan has recognized is how the University can be an effective contributor locally and globally as a mandated creator, preserver and disseminator of knowledge. Azania's concern seems to coincide with the national development agenda that expects higher education to tackle contemporary concerns one of which is aiding the transition to a knowledge society (NPC 2011). Thus, examining academic practice in Azania offers a deeper understanding of how national demands are understood and incorporated in the practice of an institution emerging from the underprivileged status in a democratic South Africa.

\section{The rising knowledge society and academic practice}

The idea of a rising knowledge society stems from the expectations of the national development plan that require all sectors of the economy to be promoted in a manner that allows transition into a knowledge society (NPC 2011). In the past decade, South Africa has produced white papers and policies that aim at propelling the country towards a knowledge society (Department of Science and Technology 2007). These include the 2008-2018 innovations plan (DST 2007); the National Integrated ICT Policy White Paper (Department of Telecommunications and Postal Services 2016); white paper on Science, Technology and Innovations (DST 2017); the National eStrategy (DTPS 2017) and the Industrial Policy Action Plan (Department of Trade and Industry 2017). These documents call for skills development, innovation and knowledge generation and application a basic preserve of higher education as the sector is known to produce nearly $90 \%$ of all knowledge for the country (DST 2017).

Therefore, rather than a physical environment, the rising knowledge society in South Africa is more of a policy environment in which all entities including higher education must operate in contribution to knowledge society in quest (NPC 2011). This policy environment is characterized with three policy initiatives specific to higher education operations the first being the white paper for post-school education and training that requires universities to focus more on graduate education, deepening partnership with the industry and innovation for a growing knowledge society (DHET 2014a, b). The second is the Human Resource Development Strategy 2010-2030 that is calling for among other things, an increase in postgraduate degrees and honours graduates in science, engineering and technology from universities (Republic of South Africa 2010). The third is the research output policy focusing on fostering research and other knowledge outputs among public higher education institutions for the country's development needs. In essence, universities and consequently academic practices of research, teaching and outreach have to operate in a policy environment hinged on the knowledge society agenda a basis upon which Leisyte and Dee (2012) called for an investigation of academic work in the face of the complex societal expectations.

So far studies interested in academic practice and its changing context of operation have been presented from a western perspective specifically reflected in the 1992 and 2007 
Carnegie and Changing Academic Profession (CAP) studies respectively (Locke and Bennion 2013; Teichler et al. 2013). The Carnegie study looked into academic work amidst the changing expectations of higher education with representation from fourteen countries and one territory none of which represented Africa. The CAP study considered South Africa yet Wolhuter (2015) based on the results of the very study to suggest an examination of academic work in contemporary South Africa. Thus, from an African experience specific to University Azania in South Africa, this study examined academic work amidst the expectations of the rising knowledge society.

\section{Theoretical perspective}

The study is guided by the neo-institutional theory. The endorsement for the theory stems from studies (Acer and Güçlü 2017; Diogo et al. 2015; Heinke 2004; Kwiek 2017; Mampaey 2018; Muzio et al. 2013) that used the theory to understand academic work in the changing environment. The neo-institutional theory is based on the assumption that organizations such as universities like Azania operate in an environment dominated by rules, beliefs, conventions and requirements of what constitutes acceptable organization forms and behavior (DiMaggio and Powell 1983; Powell 2007). The suggestion of the aforenoted studies is that the pressure from the institutional environment such as that associated with meeting the expectations of the rising knowledge society compel universities like Azania to become isomorphic in order to appear legitimate. Legitimacy stands for generalized perceptions that the actions of an entity are desirable and proper within some socially constructed system of norms, values, beliefs and definitions (Hughes and Hughes 2013). They thus suggest that since a university needs social acceptability and credibility to survive, the need for legitimacy is driving operations in universities and consequently academic practice.

DiMaggio and Powell (1983) identified the isomorphic forces shaping the quest for legitimacy as coercive, mimetic and normative. The coercive force is associated with political influence more so regulatory oversight agencies and major resource providers like government (DiMaggio and Powell 1983; Papadimitriou 2011). In essence, Azania as a public university is liable to pressure from the government as its funder as Acer and Güçlü (2017) observed that conforming to state demands is the viable way for universities to secure resources and social support. The mimetic pressure stems from the standard response to uncertainty upon which organizations learn to model others directly or indirectly (DiMaggio and Powell 1983). Thus, universities like Azania may be modeling institutions more successful than them in order to fit in which Joo et al. (2017) associated with enhancing the prestige and reputation of the organization.

Normative isomorphism arises from professionalism which Papadimitriou (2011) portrays as power and elite control shaping organizational behavior and practices to which any university Azania inclusive is no exception. The assumption therefore, is that the coercive, mimetic and normative forces are creating the pressure that is driving organizations such as universities and consequently academic practice to conform to the expectations of its context of operation, the rising knowledge society in order to secure legitimacy (Diogo et al. 2015). The neo-institutional perspective has therefore been used interpretively to explain if academic practice in University Azania is aligning or diverting from the expectations of the rising knowledge society of South Africa. 


\section{Method}

The qualitative discourse analysis guided this study to understand if academic practice in Azania is aligning or diverting from the expectations of the rising knowledge society in South Africa. Thus, relevant national and institutional documents were identified and analyzed for the study due to the value Bowen (2009) attaches to documents in understanding the discourse in specific contexts like Azania in South Africa. The national documents included annual reports of the Department of Higher Education and Training (DHET) 2012 through 2017. The selection of DHET documents was due to their capacity to aid identification of national expectations in relation to institutional operations a basis upon which the interplay of isomorphism in the relationship is explained. Institutional documents included Azania's annual reports 2012 through 2017 and the Institutional Operation Plan 2010-2014. Specificity to the selection of institutional documents relates to the Senate reports in annual reports from which secondary data on academic practices of research, teaching and outreach is availed. The period 2012-2017 was considered because DHET was formed in 2009 (DHET 2012), thus accessible annual documents are from 2012 and the accessible annual reports of Azania run up to 2017.

Like any other analytical method in qualitative research, the analysis of DHET documents involved selecting, appraising and synthesizing data to draw meaning and discover relevant insights (Bowen 2009; Gorichanaz and Latham 2016) about the expectations of the rising knowledge society in South Africa. Thus, with the support of ATLAS.ti 8.0, quotations from documents were coded, categorized and thematically analyzed. The dominant categories of ideas that emerged from the analysis are research and innovation for development, enrolment and workforce development. The identified themes guided the discussion. Secondary data from institutional documents were descriptively analyzed and discussed along the identified themes to understand if academic practice in Azania was aligning or diverting from the expectations of the rising knowledge society.

\section{Results and discussion}

This section covers the findings and discussion in relation to the themes that emerged from the analysis of DHET annual reports 2012-2017. The themes are discussed in comparison to the secondary data from Azania's annual reports 2012-2017. The goal is to establish if academic practice in Azania is aligning or diverting from the expectations of the rising knowledge society in South Africa upon specific examination of research, teaching and outreach in the institution. Table 1 gives a description of the themes.

\section{Research and innovation for development}

The findings indicate that university research is expected to aid socio-economic development in South Africa. It emerged that the scope of service of the university mandate is predetermined at the national level and supervised by the Department for Higher Education and Training as a channel and holder of power over the funding of such institutions. A quotation providing evidence to this effect claims that: 


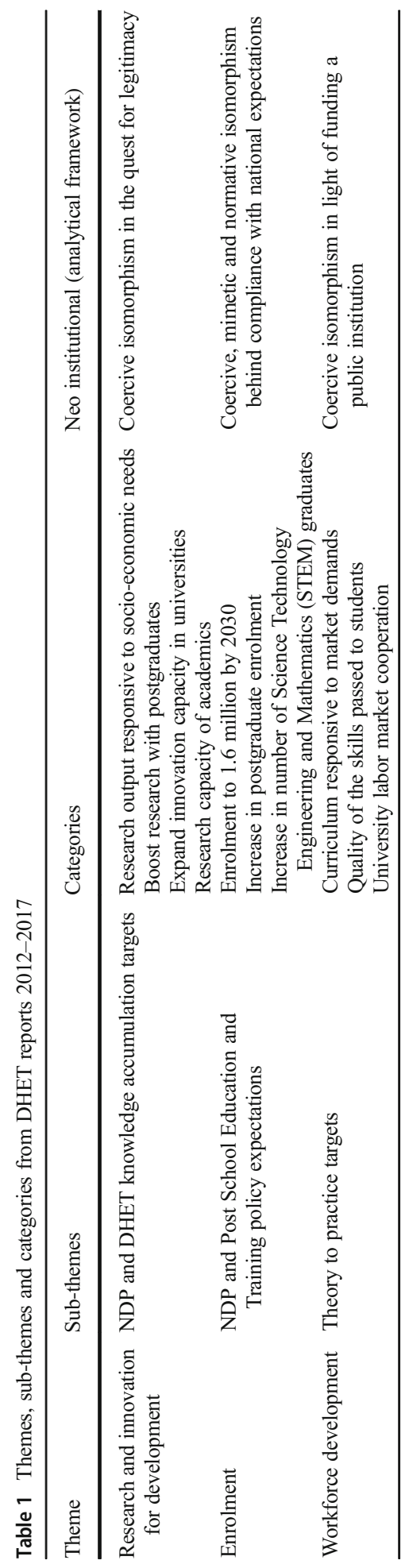


Funds transferred to support the higher education institutions (universities and universities of technology) enable them to perform their core functions-lecturing and research-efficiently and effectively. This is linked to the broader policy goals and objectives outlined in the National Plan for Higher Education, which is underpinned by the need to ensure the sustainability and responsiveness of the higher education system and to enable it to contribute to the social and economic development of South Africa (DHET Annual Report 2012).

Further evidence is provided in a quote showing one of the key strategic goals of DHET for universities as stating:

Expand research development and innovation capacity for economic and social development (DHET Annual Report 2014a, b).

The two quotes provide evidence of national expectations for the research and outreach mandate of universities in South Africa given the insinuated production and application of researched knowledge. The state university relationship suggested points to coercive isomorphism. It speaks to the commitment of universities to meet societal expectations for recognition and survival (Acer and Güçlü 2017; Hughes and Hughes 2013) a spirit in which academic practices of research and outreach are also conducted for legitimacy. Needless to say, the Annual Report (2014a, b) indicated that the University is committed to cutting edge research and innovation to generate new knowledge essential to South Africa's development an idea common with the 2015 to 2017 university's annual reports. To this end, data on publications of academics and postgraduates indicated a relatively persistent increase from 2012 through 2017. Figure 1 provides evidence to that effect.

On a more specific level, DHET through the implementation of the Research Outputs Policy expects 1.25 research units per permanent academic staff member at a traditional university (Council on Higher Education 2016). The Annual Report (2012) indicated that the university had surpassed the national research outputs target in 2011 an achievement the university has maintained as the DHET research evaluation report of 2018 indicated a rise to $3.03 \%$ for Azania (DHET 2018). Relatedly when the publications of South African researchers were measured against impact to society, the Annual Report (2012) shows that the university took the fifth position out of over twenty universities pointing to contribution to the needs in the country. The focus on knowledge production characterized by a growing postgraduate

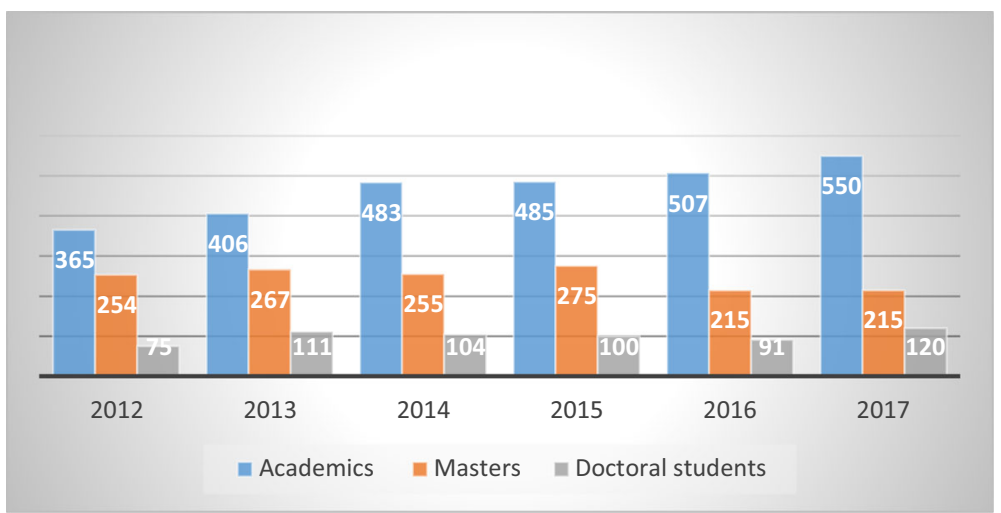

Fig. 1 Azania's publications 2012-2017 
section given the relatively stable contribution to research in Fig. 1 suggests that the research practice is responding to the rising knowledge society in South Africa since knowledge production is key to such a society.

In terms of innovation, the idea of setting up a technology transfer office (IOP 2009) marked the first major step towards bolding the university's innovation contribution to the country. In the subsequent years, the university committed its self to support the country's innovation aspirations by availing human capital and knowledge to the industry, government and the society (Annual Report 2012). By 2015, the university had 16 patent disclosures, 4 patent applications 3 option and license agreements and 21 commercialization projects (Annual Report 2015). There are two factors among others identified by the Annual Report (2017) that boosted the innovation capacity of the university, the first is the increase in the number of National Research Foundation (NRF) rated academics to 142 in 2017 from 92 in 2013. The second is the increase in the number of South African Research Chairs to 14 from the initiative of the Department of Science and Technology and NRF. The national recognition of the university's scholars points to accepted normative isomorphism.

That is, the university has embraced the selection norms like other universities in the country for recognition as an entity with the capacity to contribute to knowledge production and innovation identified as necessary for South Africa's growing knowledge-based economy (Annual Report 2017). Important to note is that the developments in innovation exist in tandem with outreach practices in fulfillment of the university's choice to make partnerships and networks to further its mandate (Annual Report 2012). Therefore, the evidence provided suggests that in fulfilling its mandate, Azania is making relatively good progress in its research and outreach practices in light of national expectations hence the practices may be aligned to the expectations of the rising knowledge society. The idea that knowledge produced is put to practical use identifies a corroboration with the findings of studies (Akker and Spaapen 2017; Altbach 2013; Bazeley 2010; Gopaul et al. 2016; Scott 2005) that observed a growing trend of academic research targeting practical needs of contemporary knowledge societies.

\section{Enrolment}

The findings revealed that the quantitative focus on enrolment in universities is critical to the national development agenda. It thus emerged that the National Development Plan identified enrolment targets with specific implementation patterns through the White Paper for Post School Education and Training. The following quotes provide evidence to this effect:

The national aim is to increase the total headcount in higher education to 1.6 million by 2030, as envisaged by the National Development Plan and the White Paper for Post School Education and Training (PSET), 2013 (DHET Annual Report 2014a, b, 2017).

Further evidence pertaining to the policy targets for enrolment states that:

The White Paper aims to improve the capacity of the Post School Education and Training system and outlines the policy directions to develop the country and improve the economic, social and cultural life of its people (DHET Annual Report 2014a, b).

In the quest of fulfilling enrolment targets, DHET warns about the shortfall to the target, key to note is: 
The skewed enrolment in universities, which sees more learners in humanities [means] universities produce fewer graduates with the skills required by the economy (DHET Annual Report 2012).

The quotations provide evidence of the relationship between enrolment in universities like Azania and the national development targets. This relationship suggests isomorphism detailing how rules and requests in the environment come to define the behavior of institutions subjected to the same environmental conditions leading to resemblance (Lawrence and Shadman 2008; Powell 2007). That is Azania like other universities in South Africa must recruit students in light of national targets and abide by teaching standards in order to equip them with the relevant knowledge and skills. To this end, data from 2012 through 2017 shows a relative increase in the number of both undergraduate and postgraduate students enrolled. Figure 2 gives details to that effect.

The persistent increase in the number of enrolled students as reflected in Fig. 2 possibly points to the response of the University to the enrolment targets for development. However, data pertaining to the same period that is 2012 through 2017 shows that the majority of the students enrolled for humanities contrary to the national target. Figure 3 gives details to that effect.

The results in Fig. 3 thus show a shortfall limiting the creation of a critical mass of STEM science, technology, engineering and mathematics workers necessary for the growing knowledge society in South Africa (DHET 2012). The evidence provided therefore, suggests that in order for Azania's teaching mandate to align to expectation, it may need to draw reference from the universities doing better in adhering to national enrolment targets.

\section{Workforce development}

The findings indicate that the emerging knowledge led development is dependent upon universities producing a workforce with the necessary knowledge and skills. It therefore emerged that what is taught to the learners, how it is taught and the quality of the knowledge and skills acquired matters. The quotes that provide evidence to the noted issues highlight that:

The system must ensure that the skills needed to drive the country's economic growth and social development are delivered at an increasing rate since available quality skills will enhance both investment and service delivery (DHET Annual Report 2012).

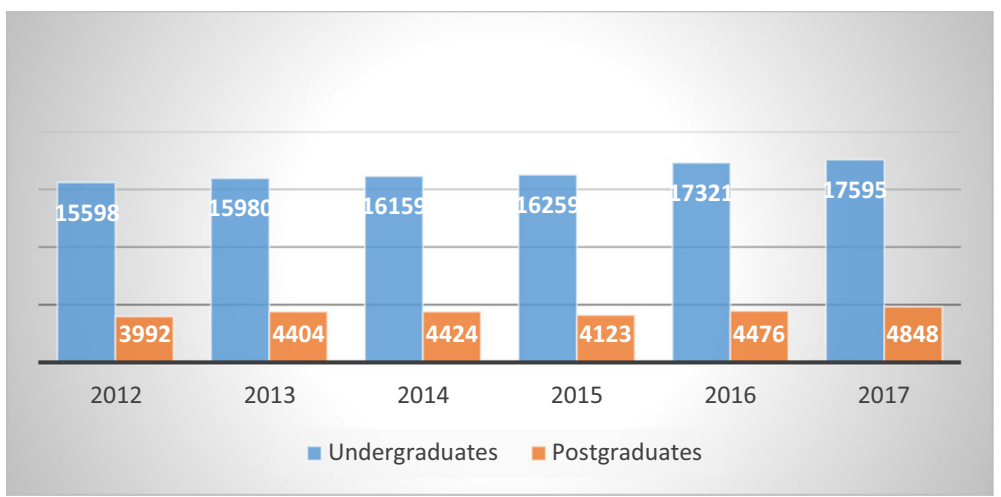

Fig. 2 Azania’s enrolment 2012-2017 


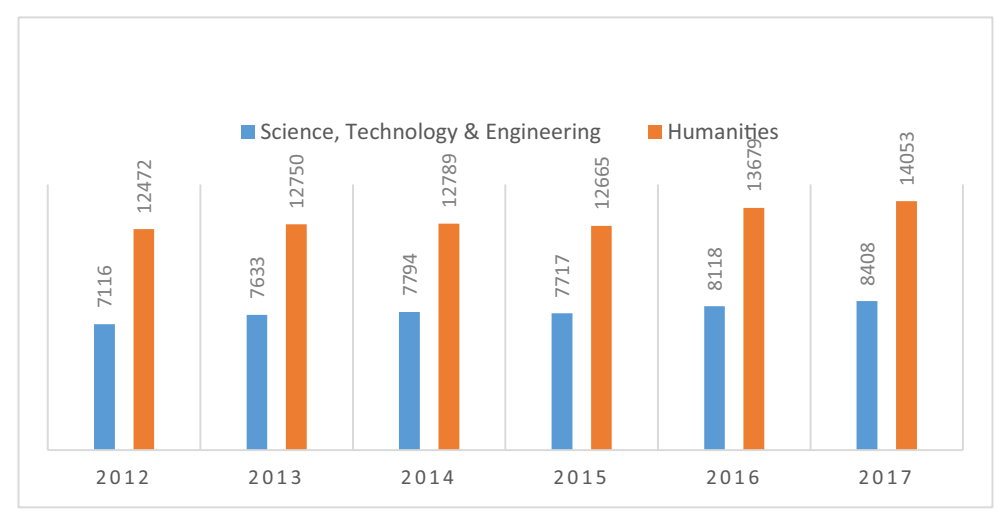

Fig. 3 Humanities versus STEM enrolment in Azania

Others state that:

There is a need for innovation in human capital for a growing knowledge economy (DHET Annual Report 2012).

Universities are expected to deliver the high-level professional and occupational skills, research and innovation required for economic growth and development (DHET Annual Report 2012)

By 2014, the expectations pertaining to workforce development noted issues such as:

Increase the number of students entering the labor market upon completion of training (DHET Annual Report 2014a, b)

Ensure a college curriculum that is responsive to the demands of the market (DHET Annual Report 2014a, b)

The statements indicate a pre-determined mandate pertaining to the teaching practice for all universities in South Africa, Azania inclusive. The nature of the expectations suggests a quest for legitimacy forcing public institutions to demonstrate relevance in order to secure funds from government (Acer and Güçlü 2017). To this end, Azania like all other public universities is aiming for a graduate tailored to national labor needs an idea portrayed in measuring the university's performance against national and system-wide targets (Annual Report 2012). Thus, to produce the nature of the graduate required in contemporary South Africa, there are three issues common in the annual reports of the university 2012 through 2017, the first being creativity in teaching and learning (Annual Report 2012, 2013, 2014a, b, 2015, 2016, 2017). As observed in the aforenoted reports, it involves using ICT in teaching and learning, availing more digital knowledge resources, building networks with the industry and community for teaching and learning purposes and student exchange programs.

The second is committing to a teaching research nexus initiated with funding research on innovative teaching and learning, Senate endorsed teaching embedded in research and research-informed curriculum reform (IOP 2009; Annual Report 2012, 2017). The third is multidisciplinarity in teaching and research to equip learners with skills and knowledge to participate equitably and confidently in the changing knowledge-driven world (Annual Report 2017). Studies that have looked into teaching in the knowledge society identified a practical 
oriented curriculum (Alam 2016; Beck 2008; Mansour 2016), inter and multidisciplinarity content (Freeman 2016) and using technology in teaching and learning as salient to preparing students for the knowledge-oriented society. Thus, the developments in the teaching practice in Azania seem to suggest a response to the rising knowledge society in South Africa. In light of the discussion, it is plausible to say that research, teaching and outreach are responding to national demands hence academic practice in Azania is aligning to the expectations of the rising knowledge society in South Africa.

\section{Conclusion}

The study intended to establish if academic practice in Azania is aligning or diverting from the expectations of the rising knowledge society in South Africa. Thus, with a qualitative discourse analysis through the national and institutional documents, the study discovered that the developments in research, teaching and outreach arising from isomorphic pressure were suggesting a response to national needs. Therefore, the study concluded that academic practice in Azania is aligning more than diverting from the expectations of the rising knowledge society in South Africa.

In lieu of the findings, two important points are discussed to offer a deeper understanding of academic practice in universities as South Africa moves towards the knowledge society. The first point relates to the fluidity of isomorphism and the second is the resistance to isomorphism. Below we put these two points into context to show the complicated nature of the developments of how universities take up and practice national mandates and policies. We juxtapose these observations with the limitation of this study, which is that we focus on policy as documents. We are cognizant that there are various levels of policy operations some of which include policy as live practice. The current data do not offer insights into this area, thus, the paper ends with a call for more research that attempts to delve into such issues.

The fluidity of isomorphism: the neo institutional theory suggests that organizations are coerced to take up practices that make them look like other organizations. The theory also suggests that organizations imitate others and change their practices to gain legitimacy. Although the data from the study shows that to a greater extent, that is, the university case under study is converging in its practices and aligning to national mandate, isomorphism appears to be fluid. University actors are strategic and align their objectives with popular demands and trends. While the current study reveals that the university is complying with government policies, it is important to see how these compliances change over time. An important component of such changes is the strategic resistance that institutions demonstrate to some of the national mandates. This brings us to the next points we discuss.

Institutional actors are not always blind or passive recipients of policies and national policies. These drives and mandates are reinterpreted, adapted, contextualized and modified. A critical point that demonstrates this is the strategic enrolments that the university is currently practicing. While the national policy calls for an increase in numbers of students in STEM, the university has continued to enroll more students in humanities. This suggests that the university resists the call for increasing numbers of students in sciences and responds more to the demands of students who are increasingly applying to the humanities. This raises serious questions on the understanding of the kinds of knowledge qualities important for knowledge societies. This shows how university actors are actually making sense of nationally driven policies. 
These two points raise a major issue for actors in higher education to consider in day-to-day practices. While the study begins to open up some contextual specificities and complexities in university integration of national mandates, more needs to be done to fully and comprehensively develop a meaningful understanding of the challenges and opportunities that knowledge societies invoke. Further research needs to explore from other research angles to understand academic work amidst the dynamic societal expectations of higher education. Furthermore, studies need to put in context the application of externally developed theoretical frameworks such as neo-institutionalism and reveal the limits or possibilities that such conceptualizations generate for African higher education conditions.

Open Access This article is distributed under the terms of the Creative Commons Attribution 4.0 International License (http://creativecommons.org/licenses/by/4.0/), which permits unrestricted use, distribution, and reproduction in any medium, provided you give appropriate credit to the original author(s) and the source, provide a link to the Creative Commons license, and indicate if changes were made.

\section{References}

Acer, E. K., \& Güçlü, N. (2017). The expansion of higher education in Turkey: The rationales behind this expansion and its challenges. Yuksekogretim Dergisi, 7(1), 28-38.

Akker, V. D. W. \& Spaapen, J. (2017). Productive interactions societal impact of academic research in the knowledge society, Leuven.

Alam, M., 2016. Challenges for teachers in knowledge society. The International Journal of Indian Psychology, 3(2). 18.01.030/20160303.

Altbach, P. G. (2013). Advancing the national and global knowledge economy: The role of research universities in developing countries. Studies in Higher Education, 38(3), 316-330.

Bazeley, P. (2010). Conceptualising research performance. Studies in Higher Education, 35(8), 889-903. https://doi.org/10.1080/03075070903348404.

Beck, S. (2008). The teacher 's role and approaches in a knowledge society. Cambridge Journal of Education, 38(4), 465-481. https://doi.org/10.1080/03057640802482330.

Boaventura, S.S. (2010). The university in the twenty-first century. In L. A. Apple, W. Micheal; Ball, J. Stephen; Gandin, ed. The Routledge international handbook of the sociology of education. New York: Routledge, pp. 274-282.

Bowen, G. A. (2009). Document analysis as a qualitative research method. Qualitative Research Journal, 9(2), 27-40. https://doi.org/10.3316/QRJ0902027.

Britz, J. J., Lor, P. J., Coetzee, I. E. M., \& Bester, B. C. (2006). Africa as a knowledge society: A reality check. International Information and Library Review, 38(1), 25-40. https://doi.org/10.1080/10572317.2006.10762700.

Cernat, M. (2011). The role of the university in the knowledge society: Ethical perspectives on academic research in the age of corporate science. Lex et Scientia International Journal, 18(1), 293.

Council on Higher Education. (2016). South African higher education reviewed: Two decades of democracy. Pretoria: Council on Higher Education.

Daniels, P. (2018). The early origins of Community Engagement at University of the Western Cape. Cape Town: University of the Western Cape.

Department of Higher Education and Training (2012). Annual Report 2011-2012, Pretoria. Available at: http://www.dhet.gov.za/SitePages/Reports.aspx. Accessed 30 Mar 2019.

Department of Higher Education and Training (2013). Annual report 2012-2013, Available at: http://www.dhet. gov.za/SitePages/Reports.aspx. Accessed 30 Mar 2019.

Department of Higher Education and Training (2014a). Annual report 2013-14, Available at: http://www.dhet. gov.za/SitePages/Reports.aspx. Accessed 30 Mar 2019.

Department of Higher Education and Training (2014b). Post-school education and training white paper for postschool education and training. Pretoria.

Department of Higher Education and Training (2015). Annual report 2014/15, Available at: http://www.dhet.gov. za/SitePages/Reports.aspx. Accessed 30 Mar 2019.

Department of Higher Education and Training (2016). Annual Report 2015/2016, Available at: http://www.dhet. gov.za/CommissionsReports/DHETAnnualReport2015-2016.pdf. Accessed 30 Mar 2019. 
Department of Higher Education and Training (2017). Annual Report 2016-2017, Available at: http://www.dhet. gov.za/SitePages/Reports.aspx. Accessed 30 Mar 2019.

Department of Higher Education and Training (2018). Report on the evaluation of the 2016 universities research output, Pretoria.

Department of Science and Technology (2007). Innovation towards a knowledge-based economy: Ten-year Plan for South Africa Department of Science and Technology. Available at: http://www.esastap.org. $\mathrm{za} /$ download/sa ten year innovation plan.pdf. Accessed 30 Mar 2019.

Department of Science and Technology (2017). White paper on science, Technology and innovation. Available at: https://bcsa.travel/wp-content/uploads/2018/02/NEW-White-Paper-Draft-1.5-V2-as-at-24-November2017.pdf. Accessed 30 Mar 2019.

Department of Telecommunications and Postal services (2017). National E-Strategy. Available at: https://www. dtps.gov.za.

Department of Telecommunications and Postal Services South Africa (2016). National Integrated ICT Policy White Paper. Government Gazette, 1212(40325), pp.4-176.

Department of Trade and Industry (2017). Industrial policy action plan 2018/19-2020/21, Pretoria.

DiMaggio, P. J., \& Powell, W. W. (1983). The Iron cage Revisted : Institutional isomorphism and collective rationality in organizational fields. American Sociological Review, 48(2), 147-160 Available at: http:/www. jstor.org/stable/2095101. Accessed 08 Apr 2019.

Diogo, S, Amaral, A \& Carvalho, T. (2015). Institutionalism and organizational change. In Multilevel governance in higher education research. Palgrave, pp. 114-132.

Freeman, I. M. (2016). Life skills for 21 st century learners. International Journal of Education and Social Sciences, 3(10), 49-52.

Gopaul, B., Jones, G. A., Weinrib, A., Metchalfe, D., Fiher, Y. G., \& Rubenson, K. (2016). The academic profession in Canada: Perceptions of Canadian University faculty about research and teaching. Canadian Journal of Higher Education, 46(2), 55-77.

Gorichanaz, T., \& Latham, K. F. (2016). Document phenomenology: A framework for holistic analysis. Journal of Documentation, 72(6), 1114-1133.

Heinke, R. (2004). Organisations and institutional environments: Neo institutionalism. In Inside the "knowledge factory." Deutscher Universitätsverlag, Wiesbaden.

Holmner, M.A. (2008). A critical analysis of information and knowledge societies with specific reference to the interaction between local and global knowledge systems. Available at: http://repository.up.ac. za/handle/2263/29381. Accessed 11 May 2019.

Hughes, W., \& Hughes, C. (2013). Professionalism and professional institutions in times of change. Building Reseach \& Information, 41(1), 28-38. https://doi.org/10.1080/09613218.2013.737096.

Industrial Development Corporation, (2017). Economic trends: Key trends in South Africa's economy. Available at: https:/www.idc.co.za/images/2017/IDC_RI_publication_Key-trends-in-SA-economy_31-March-2017.pdf. Accessed 17 Feb 2019.

Institutional Operation Plan (2009). Institutional operating Plan (2010-2014), Cape Town. Available at: http://www.uwc.ac.za. Accessed 05 Apr 2019.

Institutional Operational Plan, (2016). Institutional operating Plan 2016-2020 white paper. pp.1-56.

Jiyane, G. V., Majanja, M. K., Mostert, B. J., \& Ocholla, D. (2013). South Africa as an information and knowledge society : The benefit to informal sector women entrepreneurs. South African Journal of Libraries \& Informatio Science, 79(1), 1-12.

Joo, S., Larkin, B., \& Walker, N. (2017). Institutional isomorphism and social responsibility. Sport, Business and Management: An International Journal, 7(1), 38-57. Available at. https://doi.org/10.1108/SBM-03-2016-0010.

Kwiek, M. (2017). A generational divide in the academic profession: A mixed quantitative and qualitative approach to the polish case. European Educational Research Journal, 16(5), 645-669.

Lawrence, B.T. \& Shadman, M. (2008). Institutional theory. In The international encyclopedia of communication. Malden: Blackwell Publishing Ltd.

Leisyte, L., \& Dee, R. J. (2012). Understanding academic work in a changing institutional environment. In C. J. Smart \& B. M. Paulsen (Eds.), Higher education: Handbook of theory and research (pp. 123-206). New York: Springer.

Locke, W. \& Bennion, A. (2013). Satisfaction in stages: The academic profession in the United Kingdom and the British commonwealth. Job Satisfaction around the Academic World, pp.223-238.

Mampaey, J. (2018). Studies in higher education are higher education institutions trapped in conformity ? A translation perspective. Studies in Higher Education, 43(7), 1241-1253. https://doi.org/10.1080 /03075079.2016.1242566.

Mansour, N., (2016). Learning and teaching in the knowledge society : Challenges and potentials. In International Cnference on education. pp. 27-36. Available at: http://www.pasca.um.ac.id. Accessed 11 May 2019. 
Muzio, D., Brock, D. M., \& Suddaby, R. (2013). Professions and institutional change: Towards an institutionalist sociology of the professions. Journal of Management Studies, 50(5), 699-721.

National Planning Commission (2011). National Development Plan - Our future - make it work, Available at: http://www.nationalplanningcommission.org.za/Pages/NDP.aspx. Accessed 30 Mar 2019.

Ndofirepi, A. (2017). African universities on a global ranking scale: Legitimation of knowledge hierarchies? South African Journal of Higher Education, 31(1), 155-174. https://doi.org/10.20853/31-1-1071.

OECD (2015). OECD Economic Surveys South Africa, Paris. Available at: http://www.oecd. org/eco/surveys/South-Africa-OECD-economic-survey-overview.pdf. Accessed 17 Feb 2019.

Papadimitriou, A. (2011). The enigma of quality in Greek higher education. https://doi.org/10.3990 /1.9789036531559.

Powell, W.W. (2007). The new institutionalism. The International Encyclopedia of Organization Studies, pp. $144-145$.

Republic of South Africa (2010). Human resource development strategy for South Africa (HRD - SA) 20102030. Available at: http://www.hrdcsa.org.za. Accessed 30 Mar 2019.

Scott, P. (2005). The academic profession in a knowledge society. The formative years of scholars, pp.19-30.

Snellman, C. L. (2015). University in Knowledge Society : Role and challenges. Journal of System and Management Sciences, 5(4), 84-113.

Teichler, U., Arimoto, A., \& Cummings, W. K. (2013). The changing academic profession (1st ed.). London: Springer.

UNESCO. (2016). Knowledge societies handbook. Paris: UNESCO.

Wolhuter, C. C. (2015). New academic profession for a new South Africa? Studies in Higher Education, 40(8), 1377-1391.

Publisher's note Springer Nature remains neutral with regard to jurisdictional claims in published maps and institutional affiliations. 